\title{
PENGARUH KECEPATAN ALIRAN TERHADAP PERUBAHAN NILAI KESERAGAMAN BUTIRAN
}

\author{
Muhammad Syafaat S. Kuba \\ Universitas Muhammadiyah Makassar, Indonesia \\ Email : syafaat_skuba@unismuh.ac.id
}

\begin{abstract}
ABSTRAK
Penelitian ini bertujuan mengetahui pengaruh variasi kecepatan terhadap perubahan gradasi sedimen dasar dan tingkat keseragaman pada waktu tertentu dan untuk mendapatkan hubungan parameter berpengaruh ( $\left.v, d_{50} a w a l, t\right)$ dengan gradasi final $\left(d_{50} h a s i l\right)$. Penelitian ini menggunakan 3 variasi kecepatan dengan 3 variasi waktu pengaliran pada 3 gradasi butiran yang yang berbeda. Dalam menentukan sifat aliran digunakan parameter angka Reynold yang hasilnya ada tiga sifat aliran yang terjadi dalam penelitian ini yaitu aliran laminar pada kisar anangka Reynold sebesar 448,75 dan aliran transisi pada kisaran angka Reynold 524 dan 617 dengan 3 variasi kecepatan. Keseragaman butiran pada dasar saluran dipengaruhi oleh jumlah sedimentasi terendapkan (agradasi) dan erosi terangkut (degradasi) di sepanjang saluran atau sungai. Penyajian hasil penelitian menunjukkan bahwa volume sedimen yang hanyut akan semakin besar seiring besar kecepatan aliran dan waktu yang digunakan dengan volume butiran halus (D40) yang lebih besar volume hanyutnya dibanding butiran lain. Demikian pula sebaliknya volume yang butiran kasar lebih banyak yang tertinggal.
\end{abstract}

\section{Kata Kunci : sifat aliran, kecepatan, komposisi butiran, Angka Reynold}

\section{ABSTRACT}

This study aims to determine the effect of variations in velocity on changes in the basic sediment gradation and uniformity level at a certain time and to get the relationship of influential parameters ( $v$, d50 initial, $t$ ) with final gradation ( $d 50$ results). This study uses 3 variations of speed with 3 variations of drainage time in 3 different grain gradations. In determining the flow properties, the Reynold number parameter is used, the results of which are three flow properties that occur in this study, namely laminar flow in the Reynold range of 448.75 and the transition flow in the Reynold number range of 524 and 617 with 3 variations of speed. The uniformity of the granules at the bottom of the channel is influenced by the amount of sedimentation deposited (agradation) and transported erosion (degradation) along the channel or river. Presentation of the results of the study showed that the volume of drifting sediments would be greater along with the greater flow velocity and time used with the volume of fine grains (D40) which was greater than the other drift volume. Likewise, the volume of coarse grain is left behind.

Keywords: flow properties, velocity, grain composition, Reynold

\section{PENDAHULUAN}

Pengetahuan mengenai transport sedimen memiliki arti penting dalamkegiatan pengembangan dan pengelolaan sumbar daya air, konservasi air dan tanah serta dalam perencanaan bangunan pengamanan sungai baik permasalahan transpor sedimen secara alami maupun non alami. Permasalahan yang sering dihadapi yaitu adanya perubahan konfigurasi dasar sungai yang disebabkan oleh adanya proses 
angkutan sedimen. Dasar sungai tersusun oleh endapan material angkutan sedimen yang terbawa aliran sungai, perubahan volume angkutan sedimen tergantung pada perubahan kecepatan aliran.

Penelitian eksperimental ini bertujuan untuk mengkaji lebih lanjut sejauh mana pengaruh perubahan kondisi aliran dan variasi material dasar terhadap perubahan karakteristik gradasi material sedimen terangkut beserta keseragaman butiran. Penelitian ini merupakan penelitian yang murni yang bersifat teoritis sehingga manfaat penelitian lebih diarahkan pada pengembangan ilmu transportasi sedimen. Jenis butiran sedimen berdasarkan distribusinya dapat dibedakan menjadi butiran seragam dan butiran tidak seragam. Distribusi butiran tidak seragam memberikan pengaruh yang cukup kompleks terhadap perilaku butirannya.

\section{METODE PENELITIAN}

\section{Tempat dan Waktu Penelitian}

Penelitian akan dilaksanakan di Laboratorium Teknik Sipil Fakultas Teknik Universitas Hasanuddin Gowa, dengan waktu penelitian selama 2 bulan.

\section{Jenis Penelitian dan Sumber Data}

Jenis penelitian yang digunakan adalah Eksperimental, dimana kondisi tersebut dibuat dan diatur oleh peneliti dengan mengacu pada literatur-literatur yang berkaitan dengan penelitian tersebut, serta adanya kontrol dengan tujuan untuk menyelidiki ada-tidaknya hubungan sebab akibat serta berapa besar hubungan sebab akibat tersebut dengan cara memberikan perlakuanperlakuan tertentu pada beberapa kelompok eksperimental dan menyediakan kontrol untuk
perbandingan.Pada penelitian ini akan menggunakan dua sumber data yakni : Data primer yakni data yang diperoleh langsung dari simulasi model fisik di laboratorium dan data Sekunder yakni data yang diperoleh dari literatur dan hasil penelitian yang sudah ada baik yang telah dilakukan di Laboratorium maupun dilakukan di tempat lain yang berkaitan dengan penelitian butiran angkutan sedimentasi pada aliran sungai.

\section{Alat dan Bahan}

Penelitian ini menggunakan alat berupa saluran kaca yang dihamparkan material pasir dengan penampang bentuk segiempat. Bentuk geometris dari saluran adalah saluran lurus dengan dinding permanen, lebar dasar saluran $0.10 \mathrm{~m}$, tinggi saluran $0.30 \mathrm{~m}$ dan panjang saluran percobaan $3.0 \mathrm{~m}$. Selain saluran kaca ini alat-alat penunjang lainnya yang digunakan antara lain : Mistar ukur digunakan untuk mengukur kedalaman air, Current meter digunakan untuk mengukur kecepatan aliran, Stopwacth untuk mengukur waktu pengaliran, Kamera untuk dokumentasi, Tabel dan Alat Tulis.

Bahan yang digunakan adalah tiga variasi butiran yaitu $\mathrm{d}_{8}$ (butiran lolos ayakan 8), $\mathrm{d}_{16}$ (butiran lolos ayakan 16), $\mathrm{d}_{40}$ (butiran lolos ayakan 40).

\section{Variabel Yang Diteliti}

Sesuai dengan tujuan penelitian yang telah dikemukakan pada bab sebelumnya, maka variabel terikat yang diteliti adalah volume butiran, Koefisien pengaliran dan koefisien butiran, sedangkan variabel bebas dalam penelitian ini adalah kecepatan aliran (v), waktu pengaliran (Q).

\section{Pelaksanaan Studi Model}


Berdasarkan variabel yang akan diteliti, perancangan model pengaliran butiran didasarkan pada beberapa spesifikasi sebagai berikut : bahan yang tersedia dan ketelitian pengukuran, maka digunakan skala model, nama dan karakteristik model akan diberikan sebagai pembeda disetiap model variasinya, panjang perletakan hamparan butiran disesuaikan dengan panjang Saluranyang digunakan.

\section{Pelaksanaan Simulasi}

Pengambilan data terlebih dahulu menghampar butiran di dasar saluran dengan variasi pencampuran butiran yang telah ditentukan, mengukur kedalaman dan kecepatan air yang telah ditentukankan sebelumnya, kemudian untuk pengukuran volume dan ketebalan hamparan butiran diamati di hulu saluran. Dalam pengambilan data pengamatan kecepatan dan volume butiran diukur dan dicatat sesuai waktu yang ditentukan.

\section{Prosedur Simulasi Model}

Secara garis besar prosedur perolehan data adalah : Menentukan 3 macam diamater butiran, Pencampuran 3 macam diameter butiran berdasarkan variasi yang ditentukan, Volume masing-masing diameter butiran diukur berdasarkan variasi, pengaliran air dilakukan untuk melakukan kalibrasi alat pencatatan debit dan kecepatan air,butiran dihampar di dasar hulu saluran sampai hilir, ketebalan dan volume butiran ditentukan, setelah semua komponen siap, pelaksanaan pengamatan dimulai dengan mengalirkan air sesuai debit (Q), dan kecepatan (v) yang ditentukan, waktu (t) pengaliran air dicatat sesuai yang ditentukan, setelah pengaliran air ditutup, maka ketebalan dan volume butiran pada saluran diukur, volume masing-masing diameter butiran yang hanyut maupun yang tertinggal kembali diukur. Langkah ini dilakukan secara berulang dengan merubah variasi waktu dan variasi campuran butiran.

\section{HASIL DAN PEMBAHASAN}

Dalam penelitian ini menggunakan 3 variasi kecepatan dengan 3 variasi waktu pengaliran pada 3 macam butiran dengan komposisi pencampuran yang berbeda. Dalam menentukan sifat aliran digunakan parameter angkaReynold yang hasilnya ada tiga sifat aliran yang terjadi dalam penelitian ini yaitu aliran laminar pada kisaran angkaReynold sebesar 448,75 dan alirantransisi pada kisaran angka Reynold 524 dan 617 dengan 3 variasi kecepatan. Keseragaman butiran pada dasar saluran dipengaruhi oleh jumlah sedimentasi terendapkan (agradasi) dan erosi terangkut (degradasi) di sepanjang saluran atau sungai. Pada penelitian ini parameter yang mempengaruhi dilakukan dengan membandingkan volume angkutan sedimen pada saat awal, tertiggal dan hanyut pada saat pengaliran. Untuk melihat perubahan itu dapat dilihat pada penyajian grafik konfigurasi yang terjadi dengan variasi waktu $t_{1}=120$ detik, $t_{2}=240$ detik, $t_{3}=$ 360 detik yang dipengaruhi oleh 3 variasi kecepatan aliran $v_{1}=17,95$ $\mathrm{cm} / \mathrm{det}, v_{2}=20,96 \mathrm{~cm} / \mathrm{det}$ dan $v_{3}=$ $24,68 \mathrm{~cm} /$ det. Penyajian ini hasil running ini dapat dilihat pada tabel 4 yang menunjukkan bahwa volume sedimen yang hanyut akan semakin besar seiring besar kecepatan aliran dan waktu yang digunakan dengan volume butiran halus $\left(d_{40}\right)$ yang lebih besar volume hanyutnya di banding butiran lain. Sementara untuk melihat besarnya volume sedimen yang tertinggal dapat dilihat pada tabel 5 yang menunjukkan sebaliknya volume butiran kasar yang lebih banyak tertinggal 


\section{KESIMPULAN DAN SARAN}

Berdasarkan hasil dan pembahasan, maka dapat disimpulkan bahwa besarnya volume sedimen yang hanyut dan yang tertinggal dalam suatu saluran terbuka sangat dipengaruhi oleh besarnya kecepatan dan perubahan kemiringan dasar saluran. Dimana semakin besar kecepatan yang terjadi maka semakin besar volume sedimen yang hanyut demikian juga sebaliknya semakin kecil kecepatan maka semakin kecil pegendapan yang terjadi. Dimana parameter angka Reynold dipengaruhi oleh kedalaman air dan besarnya kecepatan yang terjadi pada saat pengaliran. Penelitian ini hanya dipengaruhi oleh kecepatan dan diameter butiran dengan kedalaman air dan debit yang dianggap konstan tanpa dilakukan pemadatan pada dasar saluran terhadap komposisi campuran butiran, maka untuk penelitian berikutnya disarankan untuk dilakukan pemadatan material sebelum melakukan penelitian dan pengambilan data untuk mendapatkan tingkat ketelitian yang sebanding dengan kondisi di lapangan. Dan disarankan juga pada penelitian dapat dilakukan pada saluran yang sifatnya berkelok-kelok.

\section{DAFTAR PUSTAKA}

Anggrahini.1997. Hidrolika Saluran Terbuka, CV. Citra Media. Surabaya.

Anwar, S. 2009, Pengelolaan Sumber Daya Air, PT. Mediatama Saptakarya Yayasan Badan Penerbit Pekerjaan Umum, Jakarta.
Breuser,H.N.C and Raudviki, AJ.1991, Scouring IAHR Hydraulik Structure Design Manual, Rotterdam, AA.Balkema.

Dewandaru, Dimas. 2013, Mewujudkan Konstruksi Jembatan Bentang Panjang yang Handal, Majalah Litbang Pekerjaan Umum, Edisi April - Juni 2013,

Julien Y. Pierre. 2002, River Menchanics, Cambridge University Press.

Kodoatie, J.R. 2009, Hidrolika Terapan Aliran pada Saluran Terbuka dan Pipa, Penerbit Andi, Yogyakarta.

Maryono, A. 2007, Restorasi Sungai, Gadja Mada University Press, Yogyakarta.

Mulyanto,H.R. 2006, Sungai Fungsi dan Sifat-Sifatnya, Graha Ilmu, Yogyakarta.

$\begin{array}{cr}\text { Munson, R.B.,Young, } & \text { F.D, } \\ \text { Okiishi,H.T., } & 2003, \\ \text { Fundamentals of } & \text { Fluids } \\ \text { Mechanic Jilid } & \text { 1, } \\ \text { Jakarta. } & \text { Erlangga. }\end{array}$

Munson,

R.B.,Young, F.D, Okiishi,H.T., 2003, Fundamentals of Fluids Mechanic Jilid 2, Erlangga. Jakarta.

Pagliara, S. \& Carnacina, L. Temporal scour evolution at bridge piers: effect of wood debris roughness and porosity, Journal of Hydraulic Research - J hydraul res, vol. 48, no. 1, pp. 3-13, 2010 
Jurnal Teknik Hidro

Volume 12 Nomor 2, Agustus 2019

Rukiyati. Kajian Degradasi Dasar Sungai dan

Penanggulangannya untuk Pengamanan Bangunan Sungai. Teknologi Sumber Daya Air, Volume 4 Nomor 3 - September 2007.

Triatmodjo, B. 2003, Hidraulika I. Yogyakarta. Beta Offset.

Triatmodjo, B. 2003, Hidraulika II. Yogyakarta. Beta Offset.

Yang,C.T. 1996, Sediment Transport Theory and Practice, The McGraw-Hill Companies,lnc, Singapura. 